\title{
The Changing Place of Development in EU-Asia Relations
}

\begin{abstract}
This article examines EU-Asia development relations from the perspective of evolving paradigmatic debates on development. In so doing, it performs two functions. First, it highlights the way in which this development theory lens can provide additional insights into EU development relations, supplementing existing analytical frames and providing further depth to explanations of policy choice and development relationships. Second, it outlines the changing shape of EU development relations with Asia, from an initial side-lining of issues of development through to the reorientation and normalisation that has been evident since 2000. This dynamic is attributed to the intersection of two elements: (i) the Union's perception of the Asian region; and (ii) the evolution in its conceptualisation of development, informed by exogenous theoretical debates. It is to the initial dissonance and subsequent congruence between these factors that the EU's changing orientation towards development in Asia may, at least in part, be attributed.
\end{abstract}

Key Words: European Union; EU Development Policy; EU-Asia Relations; Perceptions; Aid; ASEAN; ASEM

Introduction 
European Union development policy is almost as old as integration itself: five decades have now elapsed since the first Yaoundé Convention was concluded with the newly independent states of Africa, a framework that itself built upon the foundations of the earlier Articles of Association of the Treaty of Rome focused on overseas territories and colonial dependencies of the Member States. In that time, the Union has become one of the most significant donors of development assistance, the European institutions, for example, having committed €9.9 billion in 2014 (European Commission, 2015: 21) ${ }^{1}$. In the Union's own words, it is 'at the core of worldwide efforts to improve lives through development' (European Commission, 2013: 10).

Notwithstanding the intent to act globally, it is evident that the Union's approach to the developing world has been geographically inconsistent, with developing countries in certain regions - Africa foremost, alongside the Caribbean and Pacific - receiving significantly more attention and resources than those elsewhere. The states of Asia provide a prominent example. Explanations for such exclusion, however, remain few, and usually Union-centric, rooted in theoretical frameworks premised either on the primacy of the EU as actor and the way in which its policy choices shape relations with the developing world (e.g. Normative Power Europe), or on the role of its Member States and institutions in determining Union preferences (e.g. historic institutionalism). Such analyses of the shape and extent of Union policy are important though incomplete explanations. Notably absent has been consideration of the wider development discipline and the conceptual debates that have taken place therein - it is an ongoing irony in the study of EU development policy that broader development theory paradigms have been largely ignored. And yet it is clear that such conceptual debates on the nature of development and underdevelopment have played a significant part in shaping the development polices of state and non-state actors 
over time, providing a context within which state and institutional preferences are formed. As a conceptual lens, therefore, this body of development theory offers potential further insights into the contours and structure of EU development policy and practice, and further nuance to existing approaches (Doidge, 2014).

Taking a step back from Union-centric explanations, this article views EU development policy and its relations with developing countries in the context of evolving debates around development, in so doing recognising the importance of these exogenous influences in defining its development relations. Focusing on the EU's relations with Asia (defined as the states of East and Southeast Asia), it examines the tension between two factors - (i) the Union's perceptions of Asia, and (ii) the shaping of the Union's policy framework in response to external debates on the nature of development - which has helped structure its approach to the region. It is to the intersection between these two elements - in their initial dissonance and subsequent congruence - it is argued, that the Union's initial side-lining of Asian states and more recent reorientation of its development relationship with the region may, at least in part, be attributed.

\section{The Absence of Asia}

Development has never been a priority in EU-Asia relations, notwithstanding historical ties and the significant development issues that have, at varying times, confronted the region. As the Union was establishing its core development frameworks in the decades following the Treaty of Rome, for example, the majority of Asian states stood at very similar levels of economic development (in terms of per capita GDP) to their counterparts in Africa (see Table 1), and had comparable colonial backgrounds (particularly following the United Kingdom's accession in 1973). And yet, notwithstanding such commonalities, they found 
themselves excluded from the development frameworks - the Yaoundé Convention and, most importantly, the Lomé Convention - that the EU was building with its African, Caribbean and Pacific (ACP) partners. As a consequence of such exclusion, assistance to the region has historically been at a much lower level, and has tended to be more ad hoc and short-termist in nature. It was not until 1974, for example, that a programme of Financial and Technical Assistance (FTA) was put in place, allowing the Union for the first time to provide programmed development interventions. Prior to this, support to the region had been limited to humanitarian relief. Subsequently, in the 25 years to 1991, the Union allocated some $€ 1.2$ billion in aid to East and Southeast Asia (European Commission, 1994a: 30), a figure dwarfed by the $€ 15.5$ billion received by the ACP over the same period. Further, it was not until the passage of the 1992 Asia-Latin America (ALA) Regulation that the EU moved from a one-year to five-year planning cycle for its programmes in the region. In short, Asian developing countries received very different treatment from that of their ACP counterparts.

Making the contrast more stark has been the way in which the Union has defined itself as a development actor and its relations with developing countries. The EU has always portrayed its relations with the developing world in a very specific way - as an expression of 'the solidarity which binds Europe and the overseas countries' and the 'desir[e] to ensure their development and prosperity' (Preamble to the Treaty of Rome), reflecting a sense of ethical or moral obligation (Grilli, 1993: 3) to 'shoulder its responsibilities' (European Commission, 1971: 14). In this respect, it has been characterised as a 'purely humanitarian aim' (Lemaignen, 1960: 1), implying that need is the driving factor, and has been associated with principles such as equity and social justice: 'the fight for a new, more just and more equitable, economic order' said Commissioner for Development Claude Cheysson, 'cannot 
be confined to the frontiers of Europe' (Cheysson, 1976: 9). That such remains central to the European vision is affirmed by the constancy of its refrain in the comments and statements of Development Commissioners: development, asserted Neven Mimica, 'build[s] on solidarity as one of the core European values' (Mimica, 2014: 2). While the impetus is clearly a global one, variation in application has been evident since the outset, with states such as those in Asia historically less well served. The Union's sense of moral or ethical obligation, its expression of solidarity, has, in other words, been only partially observed, notwithstanding early recognition that 'world-wide' includes Asia (Drieghe, 2011: 174).

\section{Explaining Absence}

EU-Asia development relations have been shaped by a number of tensions. Asian exclusion at the moment of policy formation, for example, has been attributed to factors including its relative remoteness (by comparison to francophone Africa), its vulnerability as a source of raw materials given the regional influences of China and the Soviet Union (brought sharply into focus by the events in Korea and Indochina), and to ongoing British influence (of particular significance to the France of Charles de Gaulle) (Grilli, 1993: 272-273). Such an historically rooted explanation, however, offers little to clarify the subsequent evolution of the relationship. Beyond this early reality, evident is an ongoing dynamic involving two interlocking factors that has shaped the EU-Asia development relationship over succeeding decades. It is the intersection between the EU's view of Asia and its conceptualisation of development that has defined the changing priority afforded issues of development in Europe-Asia relations. Notable, in this respect, has been the extent to which external debates on the nature of development have shaped EU policy and, as a consequence, its development relations with the region. 


\section{The Perception Factor}

In the early years of European integration, Asia was something of an invisible region. With no particular advocate for engagement among its original membership, and with limited resources to conduct its external relations, for the EU Asia was to remain the unknown other, until, that is, economic pressures began to tell. The economic rise initially of the four Asian Tigers (Hong Kong, Singapore, South Korea, Taiwan) in the 1960s and subsequently, and of more direct significance to the Union, the concerted push to follow suit by the Tiger Cubs (Indonesia, Malaysia, the Philippines, Thailand) from the end of that decade laid the foundations for a reconceptualisation of the region. From a position as suppliers of commodities and importers of manufactured goods, these countries undertook an exportled growth strategy focused on the production of labour-intensive finished goods and components, resulting in a fundamental shift in their basic patterns of trade over little more than a decade. This 'economic miracle' forced a reorientation in the Union's view of Asia from one of 'asymmetrical indifference' (Rüland, 2001: 9), to one coloured by economic interests and particularly conceptions of competition and threat, notwithstanding that such economic success was not universal in the region. ${ }^{2}$

As a consequence of this view, from the 1970s two (broadly neo-mercantilist) strands became evident in the relationship. The first was an interest in benefiting from Asian growth, stemming from a concern as to potential marginalisation in the region. Trade and market access therefore constituted key factors underpinning both the conclusion of a Cooperation Agreement with the Association of Southeast Asian Nations (ASEAN) in 1980, and the subsequent evolution of the Union's Asia policy more broadly. Where the inaugural ASEAN-EU Economic Minister's Meeting in 1985 had suggested this motivation, noting a 
need to 'strengthen the European presence' (AEMM, 1985: §14), the extent to which it had been mainlined into EU-Asia relations became fully evident in the 1990s: in its 1994 New Asia Strategy, for example, the Commission made clear that 'the main thrust of the present and future policy in Asia is related to economic matters' (European Commission 1994b: 3), warning that the Union stood 'to lose out on the economic miracle' (17).

At the same time that issues of market access were coming to the fore, a second, equally important, strand was making itself felt. The growing competitiveness of the miracle economies on the global stage fostered a European view of Asia as threat, a trend that became increasingly evident from the 1970s as the economic situation in Europe worsened following the first oil crisis. In the period from 1970 to 1984, non-oil exports from Asian developing countries to the European market doubled (Langhammer, 1986: 94). With increased pressure on 'sensitive' industrial sectors - textiles and clothing, consumer electronics, steel, ship-building etc. - the Union became progressively more protectionist, introducing a range of tariff and non-tariff barriers on imports from Asian states and leaving them rooted firmly at the bottom of its pyramid of privileges. The terms of the Multi-Fibre Agreement, for example, were tightened, with a notable reduction in quotas for major exporters (Hong Kong, South Korea and Taiwan) (Turner, 1982: 137), while a series of Voluntary Export Restraints were leveraged on a range of other products (Grilli, 1993: 281). Similarly, a tightening of the Generalised System of Preferences saw a significant reduction in the value of import concessions (Turner, 1982: 140-141). With trade in sectors such as clothing and electronics accounting for as much as 52 per cent (Hong Kong) of exports to the EU from Asian developing countries (Langhammer, 1986: 100), such measures were significant. Finally, there was a noticeable upsurge in the imposition of anti-dumping measures against Asian states through the late 1970s, 1980s and 1990s (Grilli, 1993: 283, 
van Reisen, 1999: 146-147). Between 1977 and 1983, for example, the application of such measures under Art.115 of the EEC Treaty rose from 63 to 167, with Hong Kong, South Korea and Taiwan the top three targets (Koopman, 1984: 104).

It is this Asia, viewed through the prism of economics and trade and conditioned by perceptions $^{3}$ of competition and threat, around which EU relations with the region have been built. This view established an effective baseline for the region generally, with which various thematic policy frameworks (including, prominently, development) have intersected. That such a vision has become deep-rooted may be evidenced through recent analyses of public and media perceptions affirming that, in the European gaze, Asia continues to be strongly defined both by the market opportunities it offers and by its competitive threat (Bersick et al., 2012: 279-280). It has been in the intersection between this perception of Asia and the way in which development itself has been conceived and understood by the EU (shaped in turn by external debates) that the broad shape of the development relationship between the two has been determined.

\section{The Meaning of Development}

The EU is perhaps unique among international development actors in the extent to which its approach to issues of development has changed over time, a product of the influence of exogenous theoretical frames, their contested nature, and the consequent state of flux to which understandings of development have been subject. Such paradigmatic debates on the nature of development have impacted Union policy in a number of important ways, helping, for example, to filter its core norm set into relations with the developing world (Doidge, 2014), and to drive the evolution of its core development frameworks (Doidge and Holland, 2015), conditioning the shape of its development relationships (those with Asia not least 
among them). That these conceptual debates have borne such influence on EU policy is a product both of the tabula rasa that was Union identity in the early years of integration, and of the role of the Commission as a policy entrepreneur of initially limited capacity, drawing influence from external sources (Nugent, 2000: 13) (including broader development debates) to inform its own approach. Indeed, with a development apparatus largely focused on the technocratic side of the equation, the EU has had a tradition of outsourcing development thinking and research (Santos, 2009: 98, Orbie et al., 2013: 4), leading in part to its frequent characterisation as a 'norm-taker'.

As already noted, EU development policy dates back to the early years integration, finding its first formal expression in the Yaoundé Convention, building on the foundation of the Articles of Association of the Treaty of Rome. It emerged, in other words, in the context of the birth of the Development Age, and drew its influences strongly from the emergent modernisation model which problematized underdevelopment as a deviation from an idealtype Western modernity, conceiving development in terms of replication and catch-up. The Association framework and subsequent Yaoundé Convention drew heavily on this model, focusing on facilitating 'catch up without excessive delay' by 'supporting... efforts to modernize and industrialise' (European Commission, 1961: 3).

While modernisation dominated thinking on development in the early years, it was the transformation in understanding that was to take place in the 1970 s that both demonstrated the extent to which external debates structured Union policy, and shaped the absence of Asia from the EU's core development frameworks over subsequent decades. While critiques of modernisation, particularly Structuralist concerns relating to dependent relationships and the peripherality trap, were not new, their popularisation in the form of dependency theory and related developing world calls for the establishment of a New 
International Economic Order (NIEO) uniquely among Western development actors had significant influence over EU policy-makers, altering the way the development process and the problem of underdevelopment were conceived and understood, and producing a fundamental transformation in the structures of engagement with its main development partners. Thus, while the 1971 Memorandum on a Community Policy for Development Cooperation still had its feet in modernisation, premising human progress on the ability to achieve 'economic take-off' (European Commission, 1971: 18) - a reference to Rostow's (1960) The Stages of Economic Growth - it also called for a policy shift toward the establishment 'of a more just international order' (European Commission, 1971: 8), at the core of which was the provision by developed countries of privileged market access to the developing world (19).

This transition in development thinking was concretised in the first Lomé Convention of 1975 which, in shifting to non-reciprocity in the trading relationship at the heart of the agreement, and in establishing the STABEX (and subsequently SYSMIN) scheme to addresS the problem of commodity price fluctuations, constituted a significant derogation from the free trade-centric mainstream, directly addressing the call for greater equity in the international system. It reflected the clear influence of dependency and the NIEO, recognising that 'the free play of market forces is imperfect' (Pirzio-Biroli, 1980: 5). It also, however, clashed with the Union's emerging perception of Asia.

The negotiation of Lomé had been necessitated by the 1973 enlargement, and in particular the accession of the United Kingdom which brought its own package of colonial linkages. As a consequence, the geographic scope of EU development relations came under some pressure, with the resulting extension to the Caribbean and Pacific giving rise to a new grouping - the ACP. Given the UK's close ties to states in Asia, and ongoing bilateral 
development relations of other EU states with the region (notably the Netherlands with Indonesia), there was at least the possibility that this geographic expansion might push further east. In practice, however, this was not a prospect. The European vision of Asia seen through the prism of economics and trade, and defined by perceptions of competition and threat - that had been firming throughout the 1970s, made the region essentially incompatible with a dependency-derived Lomé framework premised on granting privileged market access. This meant both that the Asian states would not be admitted to Lomé, and that the logics underpinning the Convention would not be extended to Asia to the same extent. ${ }^{4}$ In effect, therefore, the incompatibility between the exogenously-influenced conceptual frame within which EU policy was couched, and its perception of Asia, mitigated against the establishment of a comprehensive development relationship. Notwithstanding the subsequent decline of the NIEO project on the global stage, its fingerprint remained in EU policy through Lomé's market access provisions to which, even with the Convention's extension from an initial 46 to 70 developing countries by 1995, the Asian countries were never invited to accede. This may be seen as something of an irony, given the strong Asian role in the Third Worldist movement launched with the 1955 Bandung Conference, a key political antecedent to the NIEO.

\section{The Shape of EU-Asia Development Relations}

Together, these elements produced a scenario in which development issues were downplayed in EU-Asia relations. The disconnect between EU perceptions of the region and its conception of development (informed by exogenous models) meant that, notwithstanding significant and ongoing need within the region, this was never a focus of engagement. Instead, evident was a tendency to focus on the 'dynamic economies' 
(European Commission, 1990: 8) and economic cooperation 'based upon the concept of mutual benefit... [seen as] qualitatively different from development co-operation' (European Commission, 1994b: 20), an interesting assertion given the more recent framing of development as highlighted below. The poorer countries of the region - Cambodia, Laos, Myanmar and Vietnam (CLMV) - were simply grouped with their more affluent counterparts (e.g. as ASEAN) without recognising any particular development needs, or their existence was downplayed entirely, with the Asian region, for example, defined in terms of the 'successful countries' (European Commission, 1992a: Annex §3.1.2). To the extent that aid provision was considered, it was as a necessary sop to a region of 'considerable economic and political significance to the Community' (European Commission, 1981: 8). Indicative of the contrasting view held of Asia in this respect was the fact that, prior to the Lisbon Treaty, control over the main funding instruments for geographic engagement was split: funding for the ACP was overseen by the Directorate-General for Development, while that for Asia was controlled by the Directorate-General for External Relations. Relations with ACP states, in other words, were seen as a development issue, while those with Asia were seen simply as one of broader external relations.

With development not a priority, the space was opened for motivations other than need to drive the limited EU-Asia development relationship. Tellingly, even as attempts were made by the Commission to address criticisms as to the piecemeal nature of relations with the developing world through establishing a formal Community Policy for Development Cooperation (European Commission, 1971), and while acknowledging its failure to establish mechanisms to address the needs of those states not covered by the Articles of Association and the Yaoundé Convention (6), Asia remained largely invisible. Indeed, it was only as a consequence of vocal criticism of the Commission approach, most notably from the 
European Parliament (e.g. European Parliament, 1972: 27), that a programme of Financial and Technical Assistance was eventually established in 1974 and later refined through the 1981 Asia-Latin America Regulation. The provision of programmed development assistance, then, was driven not by pressing need, but rather by the expedient of being seen to do something in those countries excluded from the forthcoming Lomé Convention, with Asia bundled into a residual grouping of similarly marginalised states: the ALA.

The impact of the low priority afforded to development in EU-Asia relations was further seen in the allocation of available funding. As noted previously, resources committed under the FTA programme remained low by comparison to the ACP states: from an initial award of $€ 18$ million to cover the wider Asian region in 1976 (from which, outside of South Asia, only Indonesia benefited, receiving €1 million) (European Commission, 1981: Annex I), it had risen only to $€ 181.66$ million by 1991 , of which $€ 28.13$ million was directed to East and Southeast Asia (European Commission, 1994a: 19). By comparison, the five low income, low HDI countries in Southeast Asia (Cambodia, Indonesia, Laos, Myanmar and Vietnam) together received $€ 0.69$ per capita in the period 1976-1991. Among their low income, low HDI African counterparts covered by Lomé's European Development Fund, however, the range of receipts spanned from Nigeria (€2.45 per capita) and Zaire (€11.61 per capita) to the Comoros (€134.70 per capita) and São Tomé and Principe (€218.94 per capita) (calculated from ACP-EEC Council of Ministers, 1991: 172-174, 178-181, 1993: 110$112,137-139)$.

Notwithstanding the modesty of assistance to Asia, the situation was additionally complicated by the fact that aid was not necessarily directed toward those states for which the need was greatest. Instead, as has long been acknowledged in the literature on aid determinants (e.g. Boschini and Dollar 2007), political motivations weighed heavily in the 
selection of recipients. Geopolitical concerns, for example, meant that it was not until November 1983 that China was made eligible for assistance, with a Council decision to extend coverage of the ALA Regulation (European Commission, 1984a: 5) (though it was not until 1985 that the initial commitment of $€ 6.0$ million earmarked in 1983 was actually disbursed). The progressive opening of China, including through the găigé kāifàng (reform and opening) programme of economic reforms proposed in 1978 and implemented from 1980, had made it a more acceptable partner, leading to the intensification of EU-China relations including revised eligibility for development assistance.

Similar concerns meant that Cambodia and Vietnam were also late to the table, while Laos and Myanmar received only sporadic assistance. Typically, the poorest countries in the region were not the main recipients of aid (Holland and Doidge, 2012: 178), with the focus instead falling on those states in which the Union had a particular economic or political interest. In short, the members of ASEAN did disproportionately well, and particularly Thailand and Indonesia. European concerns both with strengthening likeminded states in the post-Vietnam War era (Grilli, 1993: 289), and with market access, drove its aid policy. Between 1976 and 1991, for example, Financial and Technical Assistance to the low income CLMV states totalled just $€ 36.95$ million, or around $€ 0.31$ per capita, while middle income Thailand received €182.11 million (or €3.26 per capita) and low income Indonesia €170.11 million (or €0.95 per capita) (calculated from European Commission, 1981: Annex I, 1986: 22, 1990: 15, 1992b: 18, 1994a: 19). Indeed, across these 25 years, programmed assistance of this type to the CLMV states stood at only one-third the level committed for food aid, humanitarian relief and disaster response (European Commission, 1994a: 30). When it came to Asia, the European Union focus was very much on emerging markets rather than developing countries. 


\section{The Emergence of Asia}

Where Asia's relative historic absence from EU development policy is explicable through the disconnect between these two elements, their reconfiguration in the post-bipolar period reflected the alignment of the Union's perceptions of Asia with its (largely externally defined) vision of development, producing notable changes in its approach to the developing countries of the region.

\section{Reconfiguring Development}

The post-bipolar transformation in the EU's conceptualisation of development, reflecting both the rise of neoliberalism and an increased emphasis on the human dimensions of development, shifted the ground under its relations with the developing world. From the 1970s the new neoliberal model gained prominence, underpinned by the two oil crises of that decade and the election of reform-minded governments in the United Kingdom and United States. Significantly, the new paradigm quickly came to dominate key multilateral organisations. By the early 1980s, the IMF and World Bank had been effectively purged of their Keynesian influences (Stiglitz, 2002: 13) in favour of this new model of economic liberalisation involving deregulation, privatisation, the maintenance of fiscal discipline, noninterference of governments in the functioning of the market, outwardly-oriented free trade, and the effective insertion of developing countries into the global economy - a package of prescriptions later termed the 'Washington Consensus'. When the developing world debt crisis struck, this framework became the centrepiece of the response in the form of Structural Adjustment Programmes (SAPs), a process which saw the application of the neoliberal model to the indebted countries. 
This new mainstream significantly reshaped the EU's conceptualisation of development and its approach to the developing world, a transition embodied in many ways in the response to Structural Adjustment. With the proliferation of IMF and World Bank SAPs during the 1980s, it became inevitable that the EU would need to address the issue: between 1979 and 1987 more than half of all World Bank adjustment lending went to ACP states (Stevens and Killick, 1989: 27). While adjustment was seen as necessary (Frisch and Boidin, 1988: 3), however, the IMF/World Bank model was viewed as too ideologically rigid by an EU interested in a more 'pragmatic and differentiated' approach (Council, 1988: 101) reflective of Lomé's 'ideological neutrality' (European Commission, 1992c: 16), and which was both non-coercive and cognisant of the social dimension of adjustment (Council, 1988: 101-102). While such an approach was formally reflected in Lomé IV's adjustment provisions (Arts.243-250), the reality proved somewhat different. Internally, the vision expressed in Lomé IV was impacted by the divergent views of some Member States: the United Kingdom, for example, adopted a position more closely aligned with the International Financial Institutions (see e.g. Hansard, 1988: col.699-700). More significant, however, was the EU's acceptance of the 'leading role' of the IMF and World Bank (Council of the EU, 1988: 103). As a consequence, their vision of adjustment came to define the parameters of EU engagement to the point where Commission officials themselves acknowledged that there was no pretence in practice to follow any other path than that laid out by the World Bank and IMF' with Lomé IV providing 'de facto support only' for their programmes (Brown, 1999: 77). The response to Structural Adjustment, then, helped make the realignment of the Union's conception of development more stark, dragging the framework further towards the new mainstream than had initially been envisaged. What became increasingly evident in the EU's vision of development was a transition from an 
understanding of the international system as a place of evident inequity (as the Union viewed it through the filter of dependency) to one which saw the market as an even playing field, and from the view that market imperfections justified schemes such as STABEX and SYSMIN (Pirzio-Biroli, 1980: 5) to one that saw such price support structures and nonreciprocal market access arrangements as producing an ongoing lack of competitiveness (European Commission, 1992a: Annex §2.2.2). Increased competitiveness and integration into a liberalised world economy (European Commission, 1992a: 11, Council, 1992: §§10, 18), alongside access to private funding through capital markets and bank loans (Council, 1992: §10), were now seen as the key to economic growth and therefore development.

Contributing further to this reorientation was the increasing prominence of alternative people-centred development frames that had emerged in various forms from the 1970 s and gained traction particularly from the 1980s, balancing the market values of neoliberalism with an emphasis on liberal political values and social concerns. By the 1990s these various strands had cohered around a framework of Human Development that, while essentially grafted on to a foundation of neoliberal market economics, was human-focused, pro-poor, concerned with equity, social justice and human rights, green, endogenous and participatory (Pieterse, 1998: 354), and was ever more embedded in international institutions. The prioritisation of poverty reduction (conceived in terms beyond simple economic deprivation) that was central to this framework, and around which the international community had progressively oriented itself over the course of the 1990s, was given formal expression in the Millennium Development Goals (MDGs).

Again, these external conceptualisations quickly found their way into EU policy. Environmental concerns became a feature from the 1980s, with the Commission publishing its first Communication on the environmental dimension of development in 1984 (European 
Commission, 1984b). Gender was introduced with the creation of a Women in Development (WID) desk in the Directorate-General for Development at the end of 1982 (reflecting the debates of the 1970s), and when the international development community later transitioned from WID to the Gender and Development approach, this too was quickly reflected in EU policy. Finally, poverty reduction and the broader Human Development focus also came to be reflected in the EU framework. Initially accorded only passing reference (see e.g. European Commission, 1990), in 1991 the Commission was signatory to a G7 Economic Summit declaration which asserted as developmental priorities the alleviation of poverty and the delivery of needs such as healthcare and education (G7, 1991: §38), and linked, however tentatively, human rights with developmental outcomes (§36).

This shifting vision of development was subsequently embedded in a series of treaties and policy documents. The Treaty on European Union provided a legal mandate for action and, reflecting the changing conception of development, established three priority objectives: (i) the sustainable economic and social development of the developing countries; (ii) their integration into the global economy; and (iii) the campaign against poverty (Art.130u[1]). Subsequently, the EU-ACP Cotonou Agreement entrenched this new vision in development practice, focusing on poverty reduction while pursuing sustainable development and the progressive integration of the ACP into the global economy (Holland and Doidge, 2012: 73-74). Finally, addressing criticisms in the 1998 OECD-DAC Peer Review as to the lack of a guiding policy document (Mackie et al., 2005: 17), the Union began a process of distilling a clear policy framework, a process that reached fruition in the 2005 European Consensus on Development which asserted the primary objective of eradicating poverty in the context of sustainable development and pursuit of the MDGs (Art.5), while prioritising support for the Least Developed Countries (LDCs). 
By the new millennium, then, the Union's conception of development had undergone significant evolution. Reflecting the new global development agenda, for the Union free market economics and global free trade had increasingly become aligned with development, while a significant refocusing on the LDCs and on 'need' had become evident. The assumption that had underpinned Lomé - that developing countries were special cases that requiring protection from fully free markets - had been rejected (though with some qualifications in the case of LDCs) in favour of a free market-centric notion of development, one which, importantly, has a certain synergy with the EU's own economic interests. The Union's conception of development, in other words, conditioned by the evolution in development thinking that gathered momentum through the 1980 s and $1990 \mathrm{~s}$, has become increasingly aligned with its broader free trade agenda. Reinforcing this trend has been a process at the global level of casting development in terms of mutual benefit, rather than within a North-South donor-recipient dyad, a frame within which the Sustainable Development Goals have very much been forged, and one which has become ever more evident in EU development rhetoric, as with Commissioner for Development Neven Mimica's assertion that '[d]evelopment policy aims for partnership based on mutual interests' (Mimica, 2014: 2). ${ }^{5}$

Significantly, this is a reorientation that has drawn the EU's role as a development actor more closely into line with its long-standing perceptions of the Asian region. That issues of trade and market opening are no-longer conceived as contrary to, but rather as supportive or indeed fundamental to development goals, has created space for the EU to pursue economic interests in a manner consistent with its development ideals, and as an expression of solidarity with the developing world. Development, in this view, need not 
involve a significant concession of economic interests in the way that the logics of Lomé arguably did.

\section{Reshaping EU-Asia Development Relations}

Just as the prior dissonance had shaped the relative absence of development from EU-Asia relations, it is in the reconceptualisation of development and its greater alignment with the Union's perception of the region that the reconfiguring of EU-Asia relations has been rooted, to an extent 'normalising' the relationship. This has been evidenced in a number of ways. First has been a notable elevation of development in dialogue, moving beyond the limited interactions previously evident. Intrinsic to the structure of Europe-Asia engagement has been the place of group-to-group interregional relations: the EU-ASEAN framework and the Asia-Europe Meeting (ASEM). With initial contact dating to 1971, a mere four years following the creation of the Association, EU-ASEAN relations were formalised through the 1980 Cooperation Agreement that remains the foundation for engagement. Notwithstanding the Agreement's recognition of the Association as a developing region, and the commitment to intensifying support for development (Art.4), the reality was that such cooperation remained almost completely off the EU-ASEAN agenda (beyond the occasional rhetorical flourish), being left for coordination under the framework for non-associated states (i.e. the ALA Regulation). In the post-bipolar period, however, development has emerged, most clearly in the form of regional integration support.

Reflecting the transition in the conceptualisation of development, the ALA Regulation was updated in 1992, establishing a new priority area - the provision of Financial and Technical Assistance for regional cooperation between developing countries, reasserting in the post-bipolar context what had long been a strand in the EU's approach to 
the developing world. While the association of regionalism with development was not new, the emergence of 'open' regionalism in the late 1980s and early 1990s, linking integration with the pursuit of economic growth through interaction with global markets, signalled something of a revival. Deeper regional integration was defined as an 'enabling vector' (European Commission, 2011: 7) for growth, itself the backbone of poverty reduction and development (4). In the context of EU-ASEAN relations, notwithstanding the greater prominence accorded to issues of development more broadly, the integration focus came to define engagement, with Union support for integration becoming a key feature of the interregional relationship. Initially raised at the tenth ASEAN-EU Ministerial Meeting in 1992, a series of formal programmes were quickly initiated: the $€ 580,000$ Institutional Development Programme for the ASEAN Secretariat was launched in 1995, followed by the $€ 4$ million ASEAN Programme for Regional Integration Support (APRIS) in 2004 and its €8.4 million (including a €1.1 million ASEAN Secretariat contribution) successor APRIS II in 2006, and most recently the €15 million ASEAN Regional Integration Support programme in 2013. As was clarified in the 2003 A New Partnership with South East Asia, deeper regional integration of ASEAN is seen as a foundational element in the promotion of the EU'S economic, political and developmental goals in the region (Holland and Doidge, 2012: 166).

As with EU-ASEAN dialogue, the ASEM process, instituted in 1996 to relaunch and deepen relations between the two regions, remained largely silent on development for much of its history. While established to be an expansive dialogue with no a priori exclusions, the motivations underpinning its creation were primarily economic, a situation echoed directly in the substance of engagement. Reinforcing this, ASEM's initial membership reflected the economic logic, with the ten Asian participants selected 'to include dynamic economies which have contributed to the region's prosperity and growth' 
(quoted in Hänggi, 2003: 208). As a consequence, trade and investment, supplemented by responses to external events, dominated dialogue. It was not until the forum's second decade that development emerged in any substantial sense onto the cooperative agenda, with the 2006 Helsinki Summit for the first time giving detailed consideration to sustainable development, with emphasis placed on poverty reduction and the pursuit of the MDGs. As such, the Summit's Helsinki Declaration on the Future of ASEM, intended to define foci for future action, included sustainable development among its priorities. Subsequently, the 2008 Beijing Declaration on Sustainable Development, while far from being a substantive document and notably lacking any suggestion as to what members might do to ensure the success of the MDGs (on which the Declaration's understanding of development was premised), underpinned the elevated profile of development in ASEM, serving as a precursor to the convening of ASEM Development Conferences in 2009 and 2010 and the fuller integration of development into discussions on a range of issues at succeeding Summits. Evident throughout has been the clear articulation of the new development mainstream, with ASEM's perennial calls for economic globalisation, liberalisation and an open, rule-based WTO-consistent multilateral trading system increasingly explicitly aligned with development (e.g. ASEM, 2008: §§15-16).

Beyond this elevation in dialogue, the second (and most prominent) aspect in reshaping EU-Asia development relations has been the refocusing on 'need'. This new centrality of need, embodied in the focus on poverty reduction and the LDCs iterated in the MDGs and the European Consensus on Development, has been logically accompanied by an increased willingness to move beyond uniform perceptions and instead to recognise diversity. This has opened space for greater differentiation in the Union's development relations. Notable in this respect has been recognition of the challenges faced by LDCS 
regardless of geography, a change reflected in two areas: (i) the Everything But Arms (EBA) initiative; and (ii) the allocation of development assistance.

The introduction of Everything But Arms in 2001, a response to the removal of nonreciprocal trade preferences for ACP states in the move from the Lomé Convention to the Cotonou Agreement, signalled clearly the willingness to refocus on need, undermining the essential geographic uniformity that had been characteristic (in different forms) of Union development relations both with Asia and with the ACP. In granting non-reciprocal duty-free and quota-free access for essentially all products (excluding armaments, and with initial transition periods for some products) to all LDCs, the EBA drew no geographic distinction, thus for the first time giving Asian LDCs access to the same framework covering their counterparts in the ACP (and indeed excluding a number of ACP states). Eight non-ACP states benefited, including Cambodia, Laos and Myanmar (alongside four South Asian states). Setting aside the substantive impact of the EBA framework, it indicated a significant normalisation in the European Union's approach to the developing countries of Asia.

This differentiation and refocusing has been further reflected in the reprioritisation of the EU's aid provision towards the poorest states. While such had been signalled as early as the 1992 ALA Regulation (Art.4), its full impact was not felt until the new millennium when the reorientation toward need had become more fully embedded. Most recently, reflecting an intent to 'target its resources where they are needed most to address poverty reduction and where they could have greatest impact' (European Commission, 2011: 9), the second iteration of the Development Cooperation Instrument (DCI) ${ }^{6}$ for 2014-2020 introduced a process of graduation whereby upper middle income countries and those representing more than one per cent of global GDP would become ineligible for bilateral 
aid. With five exemptions agreed, this comprised 16 of the 46 countries covered by the $\mathrm{DCl}$, including China, Indonesia, Malaysia and Thailand.

With need now central to aid provision, and with political and economic priorities as a consequence no-longer influencing the aid picture to the extent previously evident, something of a shift has also been apparent in regional receipts, with the poorer countries in Asia doing significantly better overall. In the period 2000-2014, the CLMV countries received $€ 1,629.07$ million (or €9.88 per capita) in assistance, far outstripping the Union's former favourites Thailand (receiving €165.52 million, €2.47 per capita) and Indonesia (receiving €795.35 million, or €3.18 per capita). In short, EU allocations to East and Southeast Asia now reflect the level of need to a far greater extent, falling broadly in line both with HDI and GNI per capita. This is not to say that political interests have been entirely absent, however, with Myanmar having experienced a significant surge in aid since the reform process begun in 2011: in 2012-2014 it received €322.15 million, compared to $€ 252.13$ million for 2000-2011. Nevertheless, it is clear that the refocusing on need and on the situation of the LDCs that has been integral to the reframing of the Union's vision of development in the post-bipolar period has significantly altered the calculus of its aid provision in Asia, a trend likely to strengthen as the process of graduation comes into effect.

\section{Conclusion}

What is evident then is that there has been an apparent change in the place of development in EU-Asia relations, and that this has been significantly shaped by the tension between, on the one hand, the European Union's perception of the Asian region and, on the other, the evolution in its conceptualisation of development as a response to exogenous theoretical debate. In this respect, the Union's baseline approach to Asia - its primarily economic focus, 
conditioned by perceptions of opportunity and threat - has remained largely consistent since its emergence as a region of interest in the 1970s, while the conceptualisation of development has undergone a fundamental shift, bringing it more closely into line with this vision of Asia. The relative absence of development in the early decades of EU-Asia relations was a product of the disconnect between this baseline and the conceptual framework within which EU development policy was couched. The influence of dependency and demands for the establishment of a New International Economic Order defined the Union's view of development and the developing world, a view most prominently given expression in the Lomé Convention covering the ACP states. At the same time, however, it precluded the extension of the Convention, the underlying logics clashing with the competitive threatbased view of Asia, a situation in which the least developed states in the region were effectively held hostage to the success of their peers. As a consequence, development and the related challenges facing many Asian states were downplayed in relations with the EU, opening space for factors other than need to determine engagement and the allocation of what assistance was available.

The subsequent shift in the Union's vision of development, a response to evolving external debates and the definition of a new mainstream underpinned by neoliberalism and Human Development, in turn conditioned the elevation of development in the relationship particularly since the turn of the millennium. By bringing the Union's conception of development and its role as a development actor more closely into line with its economic self-interest and its perception of Asia, a reconfiguring of EU-Asia relations was made possible. The synergy of development with trade liberalisation and globalisation, for example, has meant that issues of trade and market access may be pursued as the foundation of development, rather than defined as concessions to be made to developing 
countries. This has facilitated the folding of development into the Union's largely economicfocused Asia policy. In addition, the re-focusing on need has produced a willingness to view the region with greater nuance than was previously the case, contributing in practice to increased differentiation within the region, and a reconfiguration of aid allocations. The rise of development in EU-Asia relations has therefore not primarily been about the Union rectifying an absence in its relations with the developing world, but rather about its conception of development - shaped and defined by external debates - becoming aligned with its interests in Asia. 


\section{Notes}

${ }^{1}$ Though this constituted a significant drop from the preceding years.

${ }^{2}$ For example, while in 1970 the GDP per capita of the Cambodia, Laos, Myanmar and Vietnam stood at $47 \%$ of that of the Tiger Cubs, by 1980 it had slipped to $32 \%$, declining to $27 \%$ by the end of that decade (calculated from Maddison 2006).

3 Note: no ontological claims are being made as to the extent to which such perceptions reflect an objective reality.

${ }^{4}$ While the Generalised System of Preferences introduced in 1971 (which similarly reflected the logics of dependency and the NIEO) notionally gave Asian states equivalent market access to that provided under Lomé, in practice a range of restrictions made this system much less generous, and progressively less so over time.

\footnotetext{
${ }^{5}$ This offers something of a contrast to the prior position, noted above, that mutual benefit conflicted with the development relationships.
}

${ }^{6}$ The successor to a number of financing frameworks, including the ALA Regulation. 


\section{References}

ACP-EEC Council of Ministers (1991) Annual Report of the ACP-EEC Council of Ministers (1990). Luxembourg: Office for Official Publications of the European Communities.

ACP-EEC Council of Ministers (1993) Annual Report of the ACP-EEC Council of Ministers (1992). Luxembourg: Office for Official Publications of the European Communities.

ASEM (2008) Chair's Statement of the Seventh Asia-Europe Meeting, Beijing, 24-25 October. http://www.aseminfoboard.org/sites/default/files/documents/ASEM7_ChairStatement.pdf [accessed 29 February 2016]

Bersick, S., Bruter, M., Chaban, N., Iglesias, S., and Lenihan, R. (2012) Asia in the Eyes of Europe: Perceptions and Potentials. In S. Bersick, M. Bruter, N. Chaban, S. Iglesias and R. Lenihan (eds) Asia in the Eyes of Europe: Images of a Rising Giant. Baden-Baden: Nomos, pp.271-283.

Boschini, A. and Olofsgård, A. (2007) Foreign Aid: An Instrument for Fighting Communism?, Journal of Development Studies, 43(4), 622-648.

Brown, W. (1999) The EU \& Structural Adjustment: The Case of Lomé IV \& Zimbabwe. Review of African Political Economy, 26(79), 75-91.

Cheysson, C. (1976) Extracts from Mr Cheysson's statement at the first session of the Lomé Consultative Assembly, Luxembourg, 1 June. http://aei.pitt.edu/12801/1/12801.pdf [accessed 29 February 2016]

Council of the EU (1988) Council Resolution of 31 May 1988 on the Economic Situation and Adjustment Process in sub-Saharan Africa. In Council of the EU (1989) Compilation of Texts Adopted by the Council (Ministers for Development Cooperation): 1 January 1981-31 December 1988. Luxembourg: Office for Official Publications of the European Communities, pp.101-104. 
Council of the EU (1992) Declaration of the Council and of Representatives of Governments of Member States meeting in the Council on aspects of development cooperation policy in the run-up to 2000. http://ec.europa.eu/development/body/legislation/recueil/en/en01/en012.htm (accessed 29 February 2016)

Doidge, M. (2014) A Normative Power Paradox? Theory and Change in European Union Development Policy. Paper presented to the European Union Studies Association-Asia Pacific Conference 'EU in the Shadow of Asia: Changing Relationships between the EU and the Asia Pacific'; 1-2 May, Melbourne, Australia.

Doidge, M. and Holland, M. (2015) A Chronology of European Union Development Policy: Theory and Change. Korea Review of International Studies 17(1): 59-80.

Drieghe, Lotte (2011) Lomé I herbekeken: Naar een geopolitiek intergouvernementalistische analyse van de eerste Conventie tussen de Europese Economische Gemeenschap en de Afrikaanse, Caribische en Stille-Zuidzeelanden op basis van een archiefonderzoek. PhD Thesis, University of Gent, Gent, Belgium.

European Commission (1961) Association des Etats d'Outre-Mer à la Communauté: Considérations sur le futur régime d'association. COM (61) 110 final.

European Commission (1971) Commission Memorandum on a Community Policy for Development Co-operation. SEC (71) 2700.

European Commission (1981) Fourth Report from the Commission to the Council on the Implementation of the Programme of Financial and Technical Assistance to NonAssociated Developing Countries as of 31 July 1981. COM (81) 691 final. 
European Commission (1984a) Seventh Report from the Commission to the Council and the European Parliament on the Implementation of Financial and Technical Assistance to Non-Associated Developing Countries (at 31 December 1983). COM (84) 525 final.

European Commission (1984b) The Environmental Dimension of the Community's Development Policy. COM (84) 605 final.

European Commission (1986) Ninth Report from the Commission to the Council and the European Parliament on the Implementation of Financial and Technical Assistance to Latin American and Asian (LAA) Developing Countries and Other Non-Associated Developing Countries (NADCs). COM (86) 626 final.

European Commission (1990) Guidelines for Cooperation with the Developing Countries in Latin America and Asia. COM (90) 176 final.

European Commission (1992a) Development Cooperation Policy in the Run-Up to 2000: The Community's Relations with the Developing Countries Viewed in the Context of Political Union: The Consequences of the Maastricht Treaty. SEC (92) 915 final.

European Commission (1992b) Fourteenth Annual Report from the Commission to the Council and the European Parliament on the Implementation of Financial and Technical Assistance to Asian and Latin American Developing Countries at 31 December 1990. COM (92) 1590 final.

European Commission (1992c) The role of the Commission in supporting structural adjustment in ACP States. Luxembourg: Office for Official Publications of the European Communities.

European Commission (1994a) Fifteenth Annual Report from the Commission to the Council and the European Parliament on the Implementation of Financial and Technical 
Assistance to Asian and Latin American Developing Countries at 31 December 1991. COM (1994) 541 final.

European Commission (1994b) Towards a New Asia Strategy. COM (94) 314 final.

European Commission (2011) Increasing the Impact of EU Development Policy: An Agenda for Change. COM (2011) 637 final.

European Commission (2013) Annual Report 2013 on the European Union's Development and External Assistance Policies and their Implementation in 2012. Brussels: European Commission.

European Commission (2015) Annual Report 2015 on the European Union's Development and External Assistance Policies and their Implementation in 2014. Brussels: European Commission.

European Parliament (1972) Report on behalf of the Committee on External Trade Relations on the Memorandum of the Commission of the European Communities on Community development cooperation policy. Document 63/72, PE 29.955/def.

Frisch, D. and Boidin, J.-C. (1988) Structural adjustment in sub-Saharan Africa: Adjustment, Development and Equity. Europe Information: Development, DE58. Brussels: European Commission.

G7 (1991) Economic Declaration: Building World Partnership. G7 Economic Summit (London III), July London, UK. http://www.g8.utoronto.ca/summit/1991london/communique/index.html [accessed 29 February 2016]

Grilli, E. (1993) The European Community and the Developing Countries. Cambridge: Cambridge University Press. 
Hänggi, H. (2003) Regionalism through interregionalism: East Asia and ASEM. In F.-K. Liu and P. Régnier (eds) Regionalism in East Asia: Paradigm shifting? London: Routledge, pp.197-219.

Hansard (1988) Overseas Aid and Development. Hansard, HC Deb (28 July) 138 col.690-707. Koopman, G. (1984) National Protectionism and Common Trade Policy. Intereconomics, 19(3): 103-110.

Lemaignen, R. (1960) Financial Investment Aid in the Association of Overseas Countries and Territories with the European Economic Community. Statement for the Commission of the European Economic Community to the Development Assistance Group Meetings; 9-11 March, Washington DC.

Mackie, J., de Bergh, M.-L., Frederiksen, J., Zinke, J., Grimm, S., and Freres, C. (2005) Assessment of the EC Development Policy. Maastricht: ECDPM, ICEI, ODI.

Maddison, A. (2006) The World Economy - Volume 2: Historical Statistics. Paris: OECD.

Mimica, N. (2014) Hearing by the European Parliament: Introductory Statement of Commissioner-Designate Neven Mimica, 29 September. https://ec.europa.eu/commission/sites/cwt/files/commissioner_ep_hearings/mimicastatement_en.pdf [accessed 29 February 2016]

Nugent, N. (2000) At the Heart of the Union. In N. Nugent, (ed) At the Heart of the Union: Studies of the European Commission. Basingstoke: Macmillan, 1-27.

Orbie, J., Bossuyt, F., Debusscher, P., Delputte, S., Reynaert, V. and Verschaeve, J. (2013) The Normative distinctiveness of the European Union in international development stepping out of the shadow of the world bank? Paper Presented to the EUSA Conference; 9-11 May, Baltimore, USA. 
Pieterse, J.N. (1998) My Paradigm or Yours? Alternative Development, Post-Development, Reflexive Development. Development and Change, 29(2), 343-373.

Pirzio-Biroli, C. (1980) The Community's Development Policy: The View from Inside. Notes prepared for a Conference of Europeanists; 25 October Washington, USA. http://aei.pitt.edu/11823/1/11823.pdf [accessed 29 February 2016]

Rostow, W.W. (1960) The Stages of Economic Growth: A Non-Communist Manifesto. Cambridge: Cambridge University Press.

Rüland, J. (2001) ASEAN and the European Union: A Bumpy Interregional Relationship. Bonn: Zentrum für Europäische Integrationsforschung, Rheinische Friedrich-WilhelmsUniversität.

Santos, I. (2009) The Commissioner for Development. In A. Sapir (ed) Europe's economic priorities 2010-2015: Memos to the new Commission. Brussels: Bruegel, pp.94-99.

Stevens, Christopher and Killick, Tony (1989) Structural Adjustment and Lomé IV. Trócaire Development Review, 25-40.

Turner, L. (1982) Western Europe and the NICs. In L. Turner and N. McMullan (eds) The Newly Industrializing Countries: Trade and Adjustment. London: George Allen \& Unwin, pp.135-143.

van Reisen, M. (1999) EU 'Global Player': The North-South Policy of the European Union. Utrecht: International Books. 
Table 1: GDP per capita, 1950-1970 (1990 Gheary-Khamis Dollars)

\begin{tabular}{lrrrrr}
\hline & $\mathbf{1 9 5 0}$ & $\mathbf{1 9 5 5}$ & $\mathbf{1 9 6 0}$ & $\mathbf{1 9 6 5}$ & $\mathbf{1 9 7 0}$ \\
\hline Northeast Asia & 651 & 876 & 1,096 & 1,363 & 1,833 \\
Southeast Asia & 814 & 952 & 1,025 & 1,096 & 1,255 \\
South Asia & 617 & 825 & 726 & 757 & 856 \\
Africa & 894 & 981 & 1,066 & 1,197 & 1,357 \\
Western Europe & 4,598 & 5,771 & 6,940 & 8,478 & 10,312 \\
United States & 9,561 & 10,897 & 11,328 & 13,419 & 15,030 \\
\hline Source & & & &
\end{tabular}

Source: calculated from Maddison (2006) 